DOI: $\underline{\text { https://doi.org/10.32663 }}$

\title{
PERTUMBUHAN DAN HASIL KEDELAI DENGAN PENGGUNAAN AMELIORAN BATU KARANG PADA LAHAN RAWA LEBAK MENGGUNAKAN TEKNOLOGI BUDIDAYA JENUH AIR
}

(Growth and Soyben Yield With the Use Ameliorant Coral Stone on Swamp Land Using Saturated Soil Culture Technology)

\author{
Edi Susilo $^{1 *}$, Andreani Kinata ${ }^{1}$, Dian Novita ${ }^{1}$ \\ ${ }^{I}$ Program Studi Agroteknologi, Fakultas Pertanian, Universitas Ratu Samban, Bengkulu Utara \\ Jl. Jenderal Sudirman No. 87 Arga Makmur Kabupaten Bengkulu Utara 38611 \\ *Corresponding author, susilo_agr@yahoo.com
}

\begin{abstract}
Soybean is one of the secondary crops that has a good economic value. Extensification programs can be carried out in sub-optimal swamp swamps with water saturated cultivation technology. Low pH, high $\mathrm{Al}$ and Fe are the main obstacles. One of the strategies taken is the provision of coral ameliorants. The aim of this study was to obtain information on the effectiveness of coral reefs to improve the cultivation of black soybean in swamp swamps. The study was conducted in March to May 2018 at the Experimental Garden of the Faculty of Agriculture, University of Ratu Samban Arga Makmur Bengkulu Utara. The study used a randomized block design with two factorial patterns. The first factor is dose of ameliorant per plant consisted of: control, $5 \mathrm{~g}, 6 \mathrm{~g}, 7 \mathrm{~g}, 8 \mathrm{~g}, 9 \mathrm{~g}$, and $10 \mathrm{~g}$. The second factor is the ameliorant application time consists of: 4 weeks before planting (MBP), 3 WBP, 2 WBP, 1 WBP, when planting, 1 weeks after panting (WAP). The results showed that the treatment of the dose and time of application of coral ameliorants had a very significant effect on plant height and number of leaves. There is no significant interaction between the dose and time of ameliorant application to all variables observe. The best dose of ameliorant treatment is $9 \mathrm{~g}$ per plant and increasing the height and the number of leaves and trends in seed weight per plant. Time application of 1 WBP and 1 WAP is able to produce the best height and number of leaves.
\end{abstract}

Keywords: soybeans, saturated water, swamp land coral, dosage.

\begin{abstract}
ABSTRAK
Kedelai merupakan salah satu tanaman palawija yang mempunyai nilai ekonomi cukup baik. Kebutuhan kedelai semakin meningkat seiring meningkatnya jumlah penduduk, namun produksi belum mencukupi. Program ekstensifikasi dapat dilakukan di lahan suboptimal lahan rawa lebak dengan teknologi budidaya jenuh air. Rendahnya pH dan tingginya Al dan Fe merupakan kendala utama. Salah satu strategi yang ditempuh adalah pemberian amelioran batu karang. Penelitian bertujuan mendapatkan informasi efektivitas batu karang untuk perbaikan budidaya kedelai hitam di rawa lebak. Penelitian dilaksanakan Maret - Mei 2018 di Kebun Percobaan Fakultas Pertanian Universitas Ratu Samban Arga Makmur Kabupaten Bengkulu Utara. Penelitian menggunakan rancangan acak kelompok dengan pola faktorial. Faktor pertama dosis amelioran per tanaman terdiri atas : kontrol, $5 \mathrm{~g}, 6 \mathrm{~g}, 7 \mathrm{~g}, 8 \mathrm{~g}, 9 \mathrm{~g}$, dan $10 \mathrm{~g}$. Faktor kedua waktu aplikasi amelioran terdiri atas : 4 minggu sebelum tanam (MBT), 3 MBT, 2 MBT, 1 MBT, saat tanam, 1
\end{abstract}




\section{DOI: $\underline{\text { https://doi.org/10.32663 }}$}

minggu setelah tanam (MST). Hasil penelitian menunjukkan bahwa perlakuan dosis maupun waktu aplikasi amelioran batu karang berpengaruh sangat nyata terhadap tinggi tanaman dan jumlah daun. Tidak terdapat interaksi nyata antara dosis dan waktu aplikasi amelioran terhadap seтиa variabel. Perlakuan dosis amelioran terbaik yaitu $9 \mathrm{~g}$ per tanaman dan mampu meningkatkan tinggi, jumlah daun dan kecenderungan pada bobot biji per tanaman. Waktu aplikasi 1 MBT maupun 1 MST mampu menghasilkan tinggi dan jumlah daun terbaik.

Kata kunci : kedelai, jenuh air, rawa lebak, karang, dosis.

\section{PENDAHULUAN}

Kedelai merupakan salah satu tanaman palawija yang mempunyai nilai ekonomi cukup baik karena bermanfaat sebagai bahan baku makanan khas bagi masyarakat Indonesia seperti tempe, tahu, taucho, kecap dan olahan pangan lainnya. Kedelai merupakan komoditas yang perlu mendapat perhatian karena kebutuhan dalam negeri cukup tinggi, sementara luas panen dan produksi kedelai terus menurun sehingga impor terus meningkat (Endriani, et al., 2017). Kebutuhan kedelai masyarakat semakin meningkat tetapi produksi belum mencukupi. Berdasarkan data BPS (2016) kebutuhan kedelai dalam negeri cukup tinggi mencapai 2,02 juta ton per tahun, sementara produksi nasional tahun 2016 hanya 963,183 ton.

Program ekstensifikasi pertanian dapat dilakukan di lahan sub-optimal. Salah satu lahan sub-optimal yang ada di Indonesia adalah lahan rawa. Lahan rawa merupakan salah satu alternatif dalam mengatasi semakin menyusutnya lahanlahan subur di pulau Jawa akibat konversi lahan. Mulyani dan Sarwani (2013) lahan rawa lebak merupakan lahan sub-optimal yang secara alamiah mempunyai produktivitas rendah karena faktor internal dan eksternal. Lahan rawa lebak dipengaruhi oleh adanya genangan dengan lama genangan $\geq 3$ bulan dan tinggi genangan $\geq 50 \mathrm{~cm}$. Masalah yang dihadapi dalam pengembangan lahan rawa lebak adalah pengendalian air, $\mathrm{pH}$ tanah pada umumnya rendah dan ketersediaan unsur hara tanah relatif rendah dengan tingkat kesuburan tanah yang rendah sampai sedang (Haryono et al., 2013). Oleh karena itu diperlukan teknologi budidaya yang dapat menaikkan $\mathrm{pH}$ tanah dan mampu meningkatkan kesuburan tanah yaitu teknologi kombinasi ameliorasi lahan dan pengelolaan air yang tepat dengan teknologi budidaya jenuh air.

Teknik budidaya konvensional yang biasa dilakukan pada budidaya kedelai merupakan teknik budidaya yang menghasilkan produktivitas persatuan lahan yang relatif kecil sampai sedang saja dan biasanya dilakukan pada lahan non suboptimal. Budidaya pada lahan sub-optimal mempunyai beberapa kendala dalam budidaya, namun bisa diatasi dengan teknologi budidaya jenuh air. Budidaya jenuh air merupakan penanaman di atas bedengan dengan memberikan air secara terus-menerus di dalam parit, sehingga tanah di bawah perakaran menjadi jenuh air tetapi tidak tergenang (Purwaningrahayu, et al., 2004). Menurut Sahuri dan Ghulamahdi (2014), budidaya jenuh air merupakan suatu teknologi yang mempertahankan irigasi secara terus-menerus di dalam saluran sehingga tinggi muka air dalam saluran selalu tetap dan menciptakan lapisan jenuh air pada tanah. Budidaya jenuh air yaitu 


\section{DOI: https://doi.org/10.32663}

pemberian air terus-menerus sejak tanam sampai matang fisiologis. Air dialirkan melalui sekitar 10-20 cm di bawah permukaaan tanah. Menurut Ghulamahdi, et al., 2009 dan Sagala, et al., 2011, budidaya jenuh air dapat memperbaiki pertumbuhan, meningkatkan serapan hara dan meningkatkan produksi kedelai dibandingkan budidaya kering.

Keadaan jenuh air pada perakaran risosfir pertanaman merupakan keadaan yang optimal untuk pertumbuhan dan perkembangan tanaman terutama perakaran. Perakaran dengan lingkungan yang jenuh air mendukung pertumbuhan akar yang pesat, sehingga berdampak posif terhadap pertumbuhan tajuk tanaman yang ada di atas permukaan tanah. Namun terdapat tantangan dalam budidaya kedelai di lahan rawa lebak ini, diantaranya ketersediaan hara yang rendah dengan rendahnya $\mathrm{pH}$ yang rendah sehingga memerlukan input pupuk atau amelioran untuk mendapatkan hasil yang optimal. Menurut Hanafi (2008), pada tanah asam unsur-unsur hara seperti fosfor tak dapat diserap karena diikat oleh unsur alumunium (Al) dan Fe. Teknologi budidaya jenuh air ini memberi peluang untuk menekan oksidasi pirit dan dapat dilakukan dengan cara pengaturan kedalaman muka air agar kondisi tanah lebih reduktif (Sagala, et al., 2011). Untuk itu diperlukan upaya perbaikan lahan pertanian khususnya lahan rawa lebak tersebut supaya tetap produktif. Perbaikan lahan rawa lebak salah satunya menggunakan amelioran tertentu untuk perbaikan sifat fisik dan kimia tanah. Tujuan pemberian amelioran adalah upaya untuk memperbaiki lahan dari kondisi tidak subur menjadi lahan yang cukup subur dan produktif sehingga kendala dalam budidaya dapat diminimalisir.
Pemberian input dalam bentuk amelioran pada tanah dapat mengubah dan memperbaiki sifat-sifat maupun kimia tanah. Salah satu jenis amelioran untuk perbaikan kesuburan tanah adalah amelioran batu karang. Batu karang yang dimaksud di sini adalah batu karang yang telah mati yang banyak terhampar di sepanjang pantai yang wilayahnya mempunyai potensi penghasil batu karang. Umumnya wilayah yang banyak dihasilkan batu karang ini adalah wilayah yang mempunyai sediman dan daratan yang mengandung dominansi bahan kapur. Batu karang yang telah mati dan berserakan di sepanjang pantai ini umumnya kurang termanfaatkan bahkan menjadi kendala dalam proses penangkapan ikan. Bahan amelioran yang bisa digunakan salah satunya batu karang atau terumbu karang yang mati ini. Terumbu karang adalah struktur di dasar laut berupa deposit kalsium karbonat $\left(\mathrm{CaCO}_{3}\right)$ yang dihasilkan terutama oleh hewan karang (Lasano et al., 2015), merupakan struktur dasar lautan yang terdiri dari deposit kalsium karbonat $\left(\mathrm{CaCO}_{3}\right)$ yang dapat dihasilkan oleh hewan karang bekerjasama dengan alga penghasil kapur. Menurut Hardjowigeno (2002) kapur $\left(\mathrm{CaCO}_{3}\right)$ mengandung unsur $\mathrm{Ca}$, tetapi pemberian kapur kedalam tanah pada umumnya bukan karena tanah kekurangan unsur $\mathrm{Ca}$ melainkan tanah terlalau asam. Dengan naiknya nilai $\mathrm{pH}$ tanah, maka unsur-unsur hara seperti $\mathrm{P}$ akan mudah diserap dan tidak diikat oleh Fe maupun Al. Menurut Firmawan (2017), perlakuan kalsit dengan campuran sludge dan kalsit nyata meningkatkan $\mathrm{pH}$ tanah serta mampu memperbaiki pertumbuhan dan kadar hara tanaman sorgum di tanah Podsolik dari Jasinga. Selanjutnya batu karang pada umumnya mengandung unsur kalsium 


\section{DOI: $\underline{\text { https://doi.org/10.32663 }}$}

sehingga apabila bahan ini dijadikan amelioran pada tanah yang miskin unsur hara terutama tanah yang ber-pH rendah maka hal ini menjadi alternatif dalam perbaikan lahan sub-optimal tersebut khususnya rawa lebak.

Berdasarkan uraian di atas, maka perlu dilakukan penelitian untuk mendapatkan informasi tentang efektivitas amelioran batu karang sebagai sumber kalsium terutama penerapan dosis dan waktu aplikasi amelioran yang tepat untuk perbaikan budidaya kedelai hitam di rawa lebak. Penelitian ini bertujuan untuk mendapatkan informasi tentang efektivitas batu karang sebagai sumber kalsium untuk perbaikan budidaya kedelai hitam di rawa lebak dengan dosis dan waktu aplikasi yang berbeda. Luaran hasil penelitian yang diharapkan yaitu mendapatkan dosis dan waktu aplikasi amelioran batu karang yang tepat pada budidaya kedelai di lahan rawa lebak.

\section{BAHAN DAN METODE}

Penelitian dilaksanakan bulan Maret sampai Mei 2018, di Kebun Percobaan Fakultas Pertanian Universitas Ratu Samban Arga Makmur Kabupaten Bengkulu Utara. Bahan penelitian yang digunakan adalah benih kedelai hitam Detam 1, tanah rawa lebak, pupuk organik, batu karang, dan pupuk anorganik. Peralatan yang digunakan adalah timbangan digital dan $\mathrm{pH}$ meter.

Penelitian ini dilaksanakan menggunakan rancangan acak kelompok (RAK) dengan dua faktor. Faktor pertama adalah perlakuan dosis amelioran terdiri atas 7 taraf yaitu tanpa amelioran batu karang (kontrol), amelioran batu karang $5 \mathrm{~g}$ $\operatorname{tanaman}^{-1}$ (3,3 ton ha ${ }^{-1}$ ), amelioran batu karang $6 \mathrm{~g} \operatorname{tanaman}^{-1}\left(3,9\right.$ ton $\left.\mathrm{ha}^{-1}\right)$, amelioran batu karang $7 \mathrm{~g}$ tanaman $^{-1}(4,6$ ton $\mathrm{ha}^{-1}$ ), amelioran batu karang $8 \mathrm{~g}$ $\operatorname{tanaman}^{-1}\left(5,3\right.$ ton $\left.\mathrm{ha}^{-1}\right)$, amelioran batu karang $9 \mathrm{~g} \operatorname{tanaman}^{-1}$ (5,9 ton $\left.\mathrm{ha}^{-1}\right)$, amelioran batu karang $10 \mathrm{~g} \operatorname{tanaman}^{-1}(6,6$ ton $\left.\mathrm{ha}^{-1}\right)$. Faktor kedua adalah perlakuan waktu aplikasi amelioran terdiri atas 6 taraf yaitu 4 minggu sebelum tanam, 3 minggu sebelum tanam, 2 minggu sebelum tanam, 1 minggu sebelum tanam, pada waktu tanam, dan 1 minggu setelah tanam.

Kegiatan penelitian awal yang dilakukan adalah pengumpulan media topsoil tanah rawa. Media tanah dikumpulkan menjadi satu dan dicampur dengan pupuk organik berupa pupuk kandang sapi. Setelah media tanah dan pupuk kandang dicampur secara komposit dan homogen maka media tersebut dimasukkan ke dalam polybag. Bobot masing-masing media polybag sama yaitu 5 kg. Polybag yang telah selesai terisi media tanam, selanjutnya disusun sesuai denah percobaan yang telah dibuat sesuai rancangan percobaan yang diterapkan. Media tanah dalam polybag ini dibiarkan sekitar seminggu dengan tujuan untuk mendapatkan media yang matang atau media yang baik untuk pertumbuhan tanaman nantinya. Media polybag disusun sesuai denah perlakuan yang diterapkan. Media tanam polybag dimasukkan ke baskom plastik sebagai simulasi perlakuan budidaya jenuh air. Perlakuan budidaya jenuh air mempunyai arti bahwa media polybag ini digenangi air dengan ketinggian $10 \mathrm{~cm}$ di baskomnya. Arti perlakuan budidaya jenuh air yaitu budidaya kedelai dengan menjenuhi air pada media tanam selama fase pertumbuhan dan perkembangan tanaman. Pada penelitian ini menggunakan media tanah rawa lebak yang dimasukkan ke dalam polybag sebagai 


\section{DOI: $\underline{\text { https://doi.org/10.32663 }}$}

simulasi kenyataan di lapangan. Ketinggian polybag $25 \mathrm{~cm}$ atau mempunyai bobot $5 \mathrm{~kg}$ media tanah. Dari 42 kombinasi perlakuan tersebut di atas diulang empat kali sehingga terdapat 168 satuan percobaan. Penempatan semua perlakuan dalam satu kelompok percobaan dilakukan secara acak. Perlakuan amelioran batu karang diberikan sesuai dengan perlakuan yang diterapkan baik dosis maupun waktu aplikasinya.

Benih kedelai ditanam ke media sebanyak 3 benih polybag ${ }^{-1}$. Cara menanam kedelai adalah media tanah di polybag dibuat lubang tanam sebanyak 3 lubang sedalam $3 \mathrm{~cm}$, selanjutnya benih dimasukkan ke lubang tanam sebanyak 1 benih per lubang dan terakhir ditutup dengan topsoil. Untuk mendapatkan tanaman yang normal dan baik pertumbuhannya maka dilakukan penyiraman. Penyiraman pada media tanam bertujuan untuk mendapatkan media selalu terjaga kelembabannya. Penjarangan tanaman kedelai dilakukan pada umur 2 minggu setelah tanam (MST) dengan menyisakan 2 tanaman polybag ${ }^{-1}$.

Pemeliharaan tanaman meliputi pemupukan, pengendalian hama penyakit dan gulma. Pemupukan dasar dilakukan dengan cara menugal media sedalam $5 \mathrm{~cm}$ dari lubang tanam. Setengah dari dosis urea (200 kg/ha) diberikan pada saat tanam dan selebihnya pada 4 MST. Pupuk SP-36 (100 $\left.\mathrm{kg} \mathrm{ha}^{-1}\right)$ dan $\mathrm{KCl}\left(100 \mathrm{~kg} \mathrm{ha}^{-1}\right)$ diberikan seluruhnya pada saat tanam. Pengendalian hama dan penyakit dilakukan secara berkala setiap 10 hari sekali dimulai pada 2 MST menggunakan pestisida dengan dosis sesuai anjuran untuk tanaman kedelai. Pengendalian gulma dilakukan secara manual dengan cara mencabut gulma pada umur 2 MST, 5 MST, dan 8 MST. Panen kedelai dilakukan bila daun telah berwarna kuning, rontok $90 \%$, dan polong berwarna coklat. Pemanenan kedelai dilakukan dengan mencabut batangnya kemudian berangkasan dimasukkan dalam kantong kertas dan diberi label sesuai dengan kode perlakuan. Hasil panen dijemur sampai kering dan dilakukan perontokan bijinya.

Variabel yang diamati meliputi tinggi tanaman, jumlah daun, dan bobot biji per tanaman. Data hasil pengamatan dianalisis dengan sidik ragam, apabila dari hasil analisis tersebut berpengaruh nyata maka dilanjutkan dengan uji wilayah berganda Duncan (DMRT) pada taraf kepercayaan 95\% (Mattjik dan Sumertajaya, 2006).

\section{HASIL DAN PEMBAHASAN}

Pengamatan terhadap peubah pertumbuhan tanaman kedelai meliputi tinggi tanaman, jumlah daun, dan bobot biji per tanaman. Berdasarkan sidik ragam, perlakuan amelioran batu karang berpengaruh sangat nyata terhadap variabel tinggi tanaman dan jumlah daun, namun tidak berpengaruh nyata terhadap bobot biji per tanaman. Perlakuan waktu aplikasi amelioran batu karang berpengaruh nyata atau sangat nyata terhadap variabel tinggi tanaman dan jumlah daun, namun tidak berpengaruh nyata terhadap bobot biji per tanaman. Interaksi antara dosis amelioran dan waktu aplikasi amelioran menunjukkan tidak berpengaruh nyata terhadap semua variabel pengamatan (Tabel 1).

Pada variabel tinggi tanaman menunjukkan bahwa perlakuan dosis amelioran berpengaruh nyata baik umur 3 MST maupun 6 MST. Perlakuan dosis $6 \mathrm{~g}$, $7 \mathrm{~g}, 8 \mathrm{~g}, 9 \mathrm{~g}$, dan $10 \mathrm{~g}$ tanaman $^{-1}$ mampu menghasilkan tinggi tanaman tertinggi jika dibandingkan dosis $5 \mathrm{~g}$ tanaman $^{-1}$ maupun tanpa amelioran (kontrol) pada umur 3 


\section{DOI: https://doi.org/10.32663}

MST. Pada umur 6 MST, dosis amelioran $9 \mathrm{~g} \mathrm{tanaman}{ }^{-1}$ menghasilkan tinggi tanaman tertinggi namun tidak berbeda dengan $8 \mathrm{~g}$ dan $10 \mathrm{~g} \operatorname{tanaman}^{-1}$ dan berbeda nyata dengan dosis $5 \mathrm{~g}, 6 \mathrm{~g}, 7 \mathrm{~g} \operatorname{tanaman}^{-1}$ dan kontrol (Tabel 2). Hal ini menunjukkan bahwa semakin tinggi dosis yang diterapkan pada penelitian ini maka semakin tinggi menghasilkan tinggi tanaman. Pada penelitian ini menunjukkan bahwa dosis amelioran batu karang $\left(\mathrm{CaCO}_{3}\right) 9 \mathrm{~g}$ dan $10 \mathrm{~g}$ tanaman $^{-1}$ masih menghasilkan tinggi tanaman tertinggi. Semakin tinggi dosis yang diterapkan maka semakin memperbaiki kemasaman tanah atau menaikkan $\mathrm{pH}$ tanah. Menurut Handoyo, et a., (2015), pemberian dosis dolomit $\left(\mathrm{CaCO}_{3}\right) \quad 8 \quad \mathrm{~g}$ polybag ${ }^{-1}$ berpengaruh nyata terhadap kualitas kedelai hal ini ditunjukkan pada berat 100 biji 17,73 g, dan daya kecambah 82,56 \%. Namun pendapat Saputro, et al., (2017) pemberian dosis kapur dolomit sampai 2 ton $\mathrm{ha}^{-1}$ tidak berpengaruh pada tinggi tanaman akhir penelitian, jumlah polong per tanaman, berat biji kering, berat polong kering dan berat kering akar. Dosis dolomit 2 ton $\mathrm{ha}^{-1}$ setara dengan $3 \mathrm{~g} \mathrm{tan}^{-1}$ pada penelitian disisni belum menunjukkan pertumbuhan yang terbaik.

Pada perlakuan waktu aplikasi amelioran batu karang menunjukkan berpengaruh nyata terhadap variabel tinggi tanaman baik umur 3 MST maupun 6 MST. Perlakuan waktu aplikasi 2 minggu sebelum tanam dan 1 minggu sebelum tanam mampu menghasilkan tinggi tanaman tertinggi baik pada umur 3 MST maupun 6 MST, namun tidak berbeda nyata dengan 1 minggu setelah tanam maupun 3 minggu sebelum tanam (Tabel 2). Hal ini menunjukkan bahwa amelioran batu karang memerlukan waktu untuk proses dekomposisi yang nantinya siap untuk diserap oleh akar tanaman. Pada perlakuan waktu aplikasi amelioran yang terlalu lama (terutama perlakuan 4 minggu sebelum tanam) maka akan kurang berdampak positif dalam menghasilkan pertumbuhan dan perkembangan tanaman, demikian juga waktu aplikasi yang terlalu dekat dengan waktu tanam apalagi pada saat waktu tanam. Aplikasi amelioran pada waktu bersamaan tanam benih kedelai ternyata kurang baik terhadap pertumbuhan dan perkembangan tanaman. Hal ini diduga aplikasi amelioran sewaktu tanam, amelioran belum terdekomposisi dengan baik dan belum bereaksi dengan tanah.

Pada variabel jumlah daun kedelai menunjukkan bahwa perlakuan dosis amelioran berpengaruh nyata, baik umur 3 MST maupun 6 MST. Perlakuan dosis $6 \mathrm{~g}$, $7 \mathrm{~g}, 8 \mathrm{~g}, 9 \mathrm{~g}$, dan $10 \mathrm{~g}_{\text {tanaman }}{ }^{-1}$ mampu menghasilkan jumlah daun tertinggi jika dibandingkan dosis $5 \mathrm{~g}$ tanaman ${ }^{-1}$ maupun kontrol pada umur 3 MST. Pada umur 6 MST, dosis amelioran $9 \mathrm{~g} \operatorname{tanaman}^{-1}$ menghasilkan jumlah daun terbanyak namun tidak berbeda dengan $8 \mathrm{~g}, 10 \mathrm{~g}$ dan 6 g tanaman ${ }^{-1}$ dan berbeda nyata dengan dosis $5 \mathrm{~g}, 7 \mathrm{~g}^{-1}$ tanaman $^{-1}$ dan kontrol (Tabel 3). Perlakuan dosis $8 \mathrm{~g} \operatorname{tanaman}^{-1} \mathrm{ke}$ atas menunjukkan kecenderungan yang lebih baik dibandingkan dengan perlakuan lainnya dalam menghasilkan jumlah daun. Perlu dilakukan penambahan dosis dalam penelitian lanjutan untuk mengetahui masih memungkinkan menghasilkan jumlah daun yang lebih ataupun tidak. Sehingga kedepannya terdapat kepastian dalam dosis amelioran batu karang yang diterapkan. Dosis yang tepat, maka kecukupan akan hara pada tanaman akan semakin sempurna. Menurut Khinzir (2013) upaya untuk memperbaiki keasaman tanah dapat di 


\section{DOI: $\underline{\text { https://doi.org/10.32663 }}$}

lakukan dengan pengapuran. Tujuan dari pengapuran adalah untuk meningkatkan $\mathrm{pH}$ tanah, meningkatkan ketersediaan unsur hara tanaman, mengurangi kelarutan unsur beracun seperti $\mathrm{Fe}, \mathrm{Al}$ dan $\mathrm{Mn}$, memperbaiki struktur tanah, serta mempercepat perkembangan akar dan jasad renik (mikroba) terutama bakteri pengikat Nitrogen dan nitrifikasi. Fransiscus (2006) melaporkan bahwa apabila tanaman memperoleh unsur hara yang cukup mengakibatkan fotosintesis akan berlangsung dengan baik, sehingga penumpukan bahan-bahan organik hasilhasil fotosintasis dalam biji lebih banyak dan akan berpengaruh pada produksi tanaman.

Pada perlakuan waktu aplikasi amelioran menunjukkan berpengaruh nyata terhadap variabel jumlah daun baik umur 3 MST maupun 6 MST. Perlakuan 2 minggu sebelum tanam dan 4 minggu sebelum tanam mampu menghasilkan jumlah daun terbanyak pada umur 3 MST. Pada umur 6 MST menunjukkan waktu aplikasi amelioran 1 minggu sebelum tanam dan 1 minggu setelah tanam menghasilkan jumlah daun terbanyak, namun tidak berbeda nyata dengan pada waktu aplikasi saat tanam, 4 minggu sebelum tanam dan 3 minggu sebelum tanam ditunjukkan Tabel 3. Pada penelitian ini waktu aplikasi amelioran batu karang yang paling tepat adalah satu minggu sebelum tanam atau satu minggu setelah tanam. Mumpung dan Samiputra (2017), melalui hasil penelitiannya menunjukkan waktu pemberian amelioran abu janjang kelapa sawit berpengaruh sangat nyata terhadap jumlah bintil akar, umur berbunga dan jumlah polong per tanaman dan yang terbaik adalah 3 minggu sebelum tanam dengan dosis yang lebih tinggi.
Pada variabel bobot biji per tanaman menunjukkan bahwa perlakuan dosis amelioran tidak berpengaruh nyata. Terdapat kecenderungan bahwa dosis amelioran $8 \mathrm{~g}$ dan $9 \mathrm{~g}$ tanaman $^{-1}$ mampu menghasilkan bobot biji per tanaman yang lebih tinggi jika dibandingkan dengan perlakuan lainnya (Tabel 4). Dosis amelioran $8 \mathrm{~g}$ atau $9 \mathrm{~g} \operatorname{tanaman}^{-1}$ setara dengan amelioran 6 ton $\mathrm{ha}^{-1}$. Sehingga hasil penelitian ini selaras dengan Simanjuntak et al., (2015) yang menyebutkan hasil kacang tanah terbaik diperoleh sebesar 543,33 g/m ${ }^{2}$ setara dengan 3,77 ton/ha pada kombinasi dosis dolomit 6,2 ton/ha dengan dosis fosfat 0,2 ton $\mathrm{ha}^{-1}$. Dolomit merupakan sumber kalsium dan magnesium bagi tanaman. Kalsium diserap tanaman dalam bentuk $\mathrm{Ca}$, walaupun semua bentuk pupuk $\mathrm{Ca}$ mampu meningkatkan kandungan nitrogen tanaman dan meningkatkan hasil tanaman kedelai. Kecukupan kalsium menjadikan sel-sel tanaman lebih selektif dalam menyerap hara tanaman (Saifuddin 1993).

Perlakuan waktu aplikasi amelioran menunjukkan tidak berpengaruh nyata terhadap variabel bobot biji per tanaman, namun terdapat kecenderungan bahwa 2 minggu sebelum tanam, 3 minggu sebelum tanam, dan 1 minggu setelah tanam menghasilkan bobot biji per tanaman yang lebih tinggi jika dibandingkan dengan perlakuan lainnya (Tabel 4). Hal ini menunjukkan terdapat kecenderungan yang sama dengan variabel tinggi tanaman dan jumlah daun yang mana perlakuan terbaik pada variabel tinggi maupun jumlah daun memberikan hasil biji per tanaman yang baik pula. Produktivitas kedelai budidaya jenuh air pada penelitian ini berkisar 1,74 ton $\mathrm{ha}^{-1}$ sampai 2,15 ton $\mathrm{ha}^{-1}$ yang relatif masih lebih baik dan lebih tinggi jika dibanding dengan produktivitas kedelai 


\section{DOI: https://doi.org/10.32663}

nasional yaitu 1,4 ton $\mathrm{ha}^{-1}$. Namun masih lebih rendah jika dibandingkan dengan hasil penelitian Ghulamahdi, et al., (2012) menyatakan bobot kering biji per petak tertinggi diperoleh pada budidaya jenuh air (BJA) pada Anjasmoro (4,06 ton/ha) dan terendah pada budidaya kering (BK) juga pada Anjasmoro ( 0,11 ton/ha).

\section{KESIMPULAN}

Perlakuan dosis amelioran maupun perlakuan waktu aplikasi amelioran batu karang berpengaruh sangat nyata terhadap variabel tinggi tanaman dan jumlah daun namun tidak berpengaruh nyata terhadap bobot biji per tanaman. Tidak terdapat interaksi yang nyata antara dosis amelioran dan waktu aplikasi amelioran batu karang terhadap semua variabel pengamatan. Perlakuan dosis amelioran batu karang terbaik adalah $9 \mathrm{~g} \operatorname{tanaman}^{-1}$ dan mampu meningkatkan tinggi maupun jumlah daun per tanaman. Perlakuan waktu aplikasi 1 minggu sebelum tanam maupun 1 minggu setelah tanam mampu menghasilkan tinggi dan jumlah daun terbaik.

\section{SARAN}

Perlu dilakukan penelitian lanjutan dengan menerapkan perlakuan yang sama dengan waktu dan jenis tanah yang berbeda.

\section{UCAPAN TERIMA KASIH}

Penelitian ini adalah Penelitian Skim Penelitian Dosen Pemula pendanana tahun 2018. Terima kasih kepada Direktorat Riset dan Pengabdian Direktorat Jenderal Penguatan Riset dan Pengembangan Kementerian Riset, Teknologi, dan
Pendidikan Tinggi yang telah membiayai penelitian ini.

\section{DAFTAR PUSTAKA}

[BPS] Badan Pusat Statistik. 2013. Produksi, Luas Panen dan Produktivitas Palawija di Indonesia. www.bps.go.id [21 September 2013].

[BPS]. 2016. Berita Resmi Statistik. [2 Nopember 2017].

Endriani, Ghulamahdi. M., Sulistyono. E. 2017. Pertumbuhan dan hasil kedelai di lahan rawa lebak dengan aplikasi pupuk hayati dan kimia. $J$. Agron. Indonesia, Desember 2017, 45 (3):263-270. DOI: https://dx.doi.org/10.24831/jai.v45i3 14488. ISSN 2085-2916 e-ISSN 2337-3652.

Firmawan, M. A. 2017. Pengaruh Pemberian Sludge (Lumpur Limbah) Pengolahan Air Minum dan Kalsium Karbonat (CaCO3) terhadap Pertumbuhan Tanaman Sorgum pada Tanah Podsolik dari Jasinga. [Skripsi]. Departemen Ilmu Tanah dan Sumberdaya Lahan Fakultas Pertanian Institut Pertanian Bogor.

Fransiscus. 2006. Pemberian beberapa Pupuk Organik terhadap Pertumbuhan dan Produksi Kacang Tanah (Arachis hypogea L). [Skripsi]. FP-Unri, Pekanbaru. 


\section{DOI: $\underline{\text { https://doi.org/10.32663 }}$}

Ghulamahdi, M.. Arifin. S.A., Makarim. A. K, 2012. Penerapan teknologi budidaya jenuh air pada tanaman padi dan kedelai untuk meningkatkan indeks penanaman di lahan pasang surut. Prosiding Simposium dan Seminar Bersama PERAGI-PERHORTI-PERIPI-

HIGI Mendukung Kedaulatan Pangan dan Energi yang Berkelanjutan ISBN: 978-97915649-6-0 113.

Ghulamahdi, M., Melati, M. Sagala, D. 2009. Production of soybean varieties under soil culture on tidal swamps. J. Agron. Indonesian 37:226-232.

Hanafi, A. 2008. Pemanfaatan tambak tanah sulfat masam untuk budidaya rumput laut (Gracillaria verrucosa). Balai Penelitian Perikanan Pantai.

Handoyo, V.R., Soeparjono, S., Sadiman, I. 2015. Pengaruh dosis dolomit dan macam bahan organik terhadap hasil dan kualitas benih kedelai (Glycine max (L) Merr.). Berkala Ilmiah Pertanian 1(1): xx-xx.

Hardjowigeno, S. 2002. Ilmu Tanah. Akademika Pressindo, Jakarta. 283 hal.

Haryono, M. Noor, H. Syahbuddin, M. Sarwani. 2013. Lahan Rawa: Penelitian dan Pengembangan. IAARD. Press. Badan Penelitian dan Pengembangan Pertanian. Kementerian Pertanian. Jakarta.
Khinzir. 2013. Penggunaan kapur pertanian pada lahan.http://fungisidaorganik. blogspot.com/20 $13 / 09 /(21$

November 2014).

Lasano, W., Kaligis, F.F.G., Kusen, J.D. 2015. Distribusi vertikal karang batu (Scleractinia) di perairan desa Kalasey kabupaten Minahasa. Jurnal Pesisir dan Laut Tropis. Vol. 1 No. 1.

Mattjik, A.A., Sumertajaya, I.M. 2006. Perancang Percobaan dengan Aplikasi SAS dan MINITAB. Bogor: IPB Press.

Mulyani, A., Sarwani, M. 2013. Karakteristik dan potensi lahan sub optimal untuk pengembangan pertanian di Indonesia. $J$. Sumberdaya Lahan 7:47-55.

Mumpung. Y., Samiputra, A.B. 2017. Pengaruh waktu pemberian dan dosis amelioran abu janjang kelapa sawit terhadap pertumbuhan dan hasil kedelai (Glycine $\max (\mathrm{L})$. Merrill) di tanah gambut Palangka Raya. AGRISILVIKA. 1 (1), Maret 2017 Hal: 14-21 ISSN: 2549-5100.

Purwaningrahayu, R.D., Indradewa, D. Sunarminto, B.H. 2004. Peningkatan hasil beberapa varietas kedelai dengan penerapan teknologi basah. Penelitian Pertanian Tanaman Pangan. 23(1):49-58.

Sagala, D., Ghulamahdi, M., Melati, M. 2011. Pola serapan hara dan pertumbuhan beberapa varietas kedelai dengan budidaya jenuh air di 
lahan pasang surut. J. Agroqua. 9:1- Saputro, W. Sarwitri, R., Ingesti, P.S.V.R. 8. 2017. Pengaruh dosis pupuk organik dan dolomit pada lahan

Sahuri. Ghulamahdi, M. 2014. Pola serapan hara dan produksi kedelai dengan budidaya jenuh air di lahan rawa pasang surut. Prosiding Seminar Nasional Lahan Suboptimal 2014, Palembang 26-27 September 2014. ISBN : 979-587529-9.

Saifuddin, S. 1993. Kesuburan dan Pemupukan Tanah Pertanian. CV. Pustaka Buana, Bandung. pasir terhadap pertumbuhan dan hasil kedelai (Glycine max, L.Merrill). VIGOR: Jurnal Ilmu Pertanian Tropika dan Subtropika 2 (2) : 70 - 73 (2017) 70.

Simanjuntak, W., Hapsoh, Tabrani, G. 2015. Pemberian dolomit dengan pupuk fosfat terhadap pertumbuhan dan produksi tanaman kacang tanah (Arachis hypogaea (L.). JOM FAPERTA Vol. 2 No. 2 Oktober 2015. 


\section{DOI: $\underline{\text { https://doi.org/10.32663 }}$}

Tabel 1. Rekapitulasi pertumbuhan dan hasil kedelai terhadap amelioran batu karang dan waktu aplikasi yang berbeda

\begin{tabular}{|c|c|c|c|c|c|}
\hline \multirow[b]{2}{*}{ No } & \multirow[b]{2}{*}{ Variabel } & \multicolumn{2}{|c|}{ Perlakuan } & \multirow{2}{*}{$\frac{\text { Interaksi }}{\mathrm{P} \times \mathrm{W}}$} & \multirow[b]{2}{*}{ KK } \\
\hline & & $\begin{array}{c}\text { Dosis } \\
\text { amelioran } \\
\text { batu } \\
\text { karang } \\
\text { (P) }\end{array}$ & $\begin{array}{c}\text { Waktu } \\
\text { aplikasi } \\
\text { amelioran } \\
\text { (W) }\end{array}$ & & \\
\hline 1 & Tinggi tanaman umur 3 MST & $6,79 * *$ & $3,44 * *$ & $1,46 \mathrm{tn}$ & 18,64 \\
\hline 2 & Tinggi tanaman umur 6 MST & $6,83 * *$ & $2,35^{*}$ & $1,54 \mathrm{tn}$ & 31,40 \\
\hline 3 & Jumlah daun umur 3 MST & $4,23 * *$ & $7,39 * *$ & $0,92 \mathrm{tn}$ & 18,13 \\
\hline 4 & Jumlah daun umur $6 \mathrm{MST}$ & $3,97 * *$ & $2,59 *$ & $1,20 \mathrm{tn}$ & 31,89 \\
\hline 5 & Bobot biji per tanaman & $0,96 \mathrm{tn}$ & $1,26 \mathrm{tn}$ & $1,40 \mathrm{tn}$ & 32,56 \\
\hline
\end{tabular}

Keterangan : $*$ = berpengaruh nyata

$* *$ = berpengaruh sangat nyata

tn = tidak berpengaruh nyata

KK = koefisien keragaman

Tabel 2. Rataan tinggi tanaman kedelai terhadap amelioran batu karang dan waktu aplikasi yang berbeda

\begin{tabular}{ccc}
\hline \multicolumn{1}{c}{ Perlakuan } & \multicolumn{2}{c}{ Tinggi tanaman $(\mathrm{cm})$ minggu ke- } \\
\cline { 2 - 3 } & $3 \mathrm{MST}$ & $6 \mathrm{MST}$ \\
\hline Dosis amelioran batu karang : & & \\
Tanpa amelioran batu karang (P0) & $23,10 \mathrm{~b}$ & $51,79 \mathrm{~d}$ \\
Amelioran batu karang 5 g/tanaman & $24,13 \mathrm{~b}$ & $56,33 \mathrm{~cd}$ \\
Amelioran batu karang 6 g/tanaman & $28,15 \mathrm{a}$ & $66,25 \mathrm{bc}$ \\
Amelioran batu karang 7 g/tanaman & $28,25 \mathrm{a}$ & $66,88 \mathrm{bc}$ \\
Amelioran batu karang 8 g/tanaman & $29,29 \mathrm{a}$ & $77,79 \mathrm{ab}$ \\
Amelioran batu karang 9 g/tanaman & $29,40 \mathrm{a}$ & $81,65 \mathrm{a}$ \\
Amelioran batu karang 10 g/tanaman & $28,40 \mathrm{a}$ & $78,19 \mathrm{ab}$ \\
\hline Waktu aplikasi amelioran : & & \\
4 minggu sebelum tanam & $26,25 \mathrm{bc}$ & $61,70 \mathrm{bc}$ \\
3 minggu sebelum tanam & $25,41 \mathrm{c}$ & $70,77 \mathrm{abc}$ \\
2 minggu sebelum tanam & $30,11 \mathrm{a}$ & $71,73 \mathrm{abc}$ \\
1 minggu sebelum tanam & $28,16 \mathrm{abc}$ & $74,48 \mathrm{a}$ \\
Pada waktu tanam & $26,27 \mathrm{bc}$ & $59,48 \mathrm{c}$ \\
1 minggu setelah tanam & $28,70 \mathrm{ab}$ & $72,30 \mathrm{ab}$ \\
\hline
\end{tabular}

Keterangan : Angka-angka yang diikuti huruf yang sama pada kolom yang sama tidak berbeda nyata pada uji DMRT taraf $5 \%$. 
Tabel 3. Rataan jumlah daun kedelai terhadap amelioran batu karang dan waktu aplikasi yang berbeda

\begin{tabular}{ccc}
\hline \multirow{2}{*}{ Perlakuan } & \multicolumn{2}{c}{ Jumlah daun (helai) minggu ke- } \\
\cline { 2 - 3 } & $3 \mathrm{MST}$ & $6 \mathrm{MST}$ \\
\hline Dosis amelioran batu karang : & & \\
Tanpa amelioran batu karang (P0) & $4,67 \mathrm{~b}$ & $7,63 \mathrm{~d}$ \\
Amelioran batu karang 5 g/tanaman & $4,56 \mathrm{~b}$ & $8,88 \mathrm{bcd}$ \\
Amelioran batu karang 6 g/tanaman & $5,54 \mathrm{a}$ & $9,29 \mathrm{abcd}$ \\
Amelioran batu karang 7 g/tanaman & $5,27 \mathrm{a}$ & $8,27 \mathrm{~cd}$ \\
Amelioran batu karang 8 g/tanaman & $5,40 \mathrm{a}$ & $10,38 \mathrm{ab}$ \\
Amelioran batu karang 9 g/tanaman & $5,48 \mathrm{a}$ & $11,10 \mathrm{a}$ \\
Amelioran batu karang 10 g/tanaman & $5,08 \mathrm{ab}$ & $9,92 \mathrm{abc}$ \\
\hline Waktu aplikasi amelioran : & & \\
4 minggu sebelum tanam & $5,57 \mathrm{ab}$ & $9,36 \mathrm{ab}$ \\
3 minggu sebelum tanam & $5,16 \mathrm{bc}$ & $9,48 \mathrm{ab}$ \\
2 minggu sebelum tanam & $5,86 \mathrm{a}$ & $7,94 \mathrm{~b}$ \\
1 minggu sebelum tanam & $4,80 \mathrm{c}$ & $10,21 \mathrm{a}$ \\
Pada waktu tanam & $4,71 \mathrm{c}$ & $8,75 \mathrm{ab}$ \\
1 minggu setelah tanam & $4,75 \mathrm{c}$ & $10,36 \mathrm{a}$ \\
\hline
\end{tabular}

Keterangan : Angka-angka yang diikuti huruf yang sama pada kolom yang sama tidak berbeda nyata pada uji DMRT taraf 5\%.

Tabel 4. Rataan bobot biji per tanaman kedelai terhadap batu karang dan waktu aplikasi yang berbeda

\begin{tabular}{lc}
\hline \multicolumn{1}{c}{ Perlakuan } & Bobot biji per tanaman $(\mathrm{g})$ \\
\hline Dosis amelioran batu karang : & $7,73 \mathrm{a}$ \\
Tanpa amelioran batu karang (P0) & $7,63 \mathrm{a}$ \\
Amelioran batu karang $5 \mathrm{~g} /$ tanaman & $7,75 \mathrm{a}$ \\
Amelioran batu karang $6 \mathrm{~g} / \operatorname{tanaman}$ & $7,00 \mathrm{a}$ \\
Amelioran batu karang $7 \mathrm{~g} /$ tanaman & $8,17 \mathrm{a}$ \\
Amelioran batu karang $8 \mathrm{~g} /$ tanaman & $8,63 \mathrm{a}$ \\
Amelioran batu karang 9 g/tanaman & $7,58 \mathrm{a}$ \\
Amelioran batu karang 10 g/tanaman & \\
\hline Waktu aplikasi amelioran : & $6,95 \mathrm{a}$ \\
4 minggu sebelum tanam & $8,21 \mathrm{a}$ \\
3 minggu sebelum tanam & $8,11 \mathrm{a}$ \\
2 minggu sebelum tanam & $7,54 \mathrm{a}$ \\
1 minggu sebelum tanam & $7,54 \mathrm{a}$ \\
Pada waktu tanam & $8,36 \mathrm{a}$ \\
\hline minggu setelah tanam &
\end{tabular}

